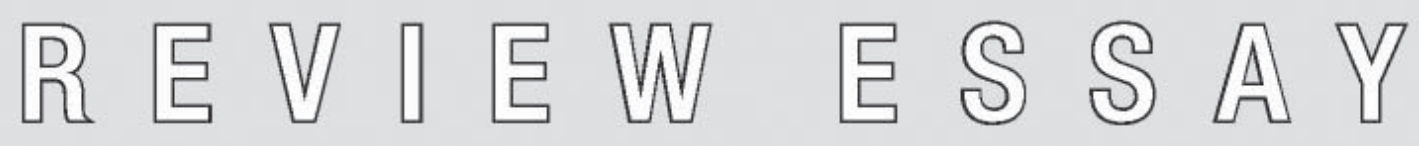
af Poul Pedersen

\title{
Orientalism, Said og amerikansk antropologi
}

Den fremtrædende amerikanske mellemøstforsker, Malcolm Kerr, anmeldte i 1980 Edward Saids Orientalism. På sin egen friske måde beskrev han bogen således:

This book reminds me of the television program "Athletes in Action", in which professional football players compete in swimming, and so forth. Edward Said, a literary critic loaded with talent, has certainly made a splash, but with this sort of effort he is not going to win any major races (Kerr 1980:544). ${ }^{1}$

Kerr fejlbedømte fuldstændig Saids vinderchancer, for Orientalism blev en megasejr (for nu at blive i Kerrs sportsterminologi). I følge Encyclopedia Britannica er den blandt det tyvende århundredes mest indflydelsesrige bøger, den er oversat til 36 sprog og er efter mere end 30 år i handelen stadig godt sælgende. Orientalism gjorde Edward Said verdenskendt, og ifølge den norske antropolog Thomas Hylland Eriksen var Said "en af de vigtigste skikkelser i verden i de sidste to tiår af den 20. århundrede" (Eriksen 2003:10).

Jeg har nok selv fejlbedømt Orientalism's chancer, dog ikke så voldsomt som Kerr. For ti år siden skrev jeg, at Saids indflydelse var vigende, og at vi var på vej ind i en post-Saidisk æra (Pedersen 1998). Det er jeg ikke så sikker på nu, for de sidste fem-seks år har der været en meget stor international opmærksomhed om både Said og Orientalism. Det begyndte i 2003 i anledning af 25-året for bogens udgivelse og blev forstærket efter Saids død den 25. september 2003. I 2008 kom der en lang række markeringer af Orientalism's 30års jubilæum. Den tilspidsede situation i Mellemøsten bidrager formodent- 
lig også til at fastholde opmærksomheden, for Said var jo ikke blot forfatter til Orientalism, men også en fremtrædende talsmand for den palæstinensiske sag. Måske er Said og hans værk mere populære end for ti år siden, og man skal næppe tro, at Orientalism er ved at gå i glemmebogen.

Når Kerrs spådom så eftertrykkeligt blev gjort til skamme, hænger det muligvis sammen med, at Kerr ikke havde øje for den større sammenhæng, Orientalism kom til at virke i, og hvor den fik sin store udbredelse: En verden, hvor der i stigende grad kom fokus på forholdet mellem viden og magt, og hvor hævdvundne grænser mellem politik og videnskab sløredes. Det var den slags, Saids bog drejede sig om - og det for et lærdomshistorisk værk på en meget polemisk og provokerende politisk måde. Said hævdede, at "orientalismen" og "orientalisterne" var medskyldige i Vestens og vesterlændingenes overgreb på Orientens befolkninger, som de er foregået i kolonialistisk, imperialistisk eller anden sammenhæng. Saids orientalismeprojekt (eller rettere "anti-orientalismeprojekt") har en forløber i antropologien. Siden afkoloniseringens begyndelse i 1950'erne har antropologer - nogle, ikke dem alle diskuteret deres fags historiske og aktuelle ansvar for den asymmetriske verdensorden, eller - med Marshall Sahlins' ord - opdelingen af verden i Vesten og resten ("the distinction between the West and the rest" (Sahlins 1976:54)). Said berører ikke i Orientalism denne beslægtede antropologiske forløber for hans eget projekt, og i det hele taget er det meget lidt, han har at sige om antropologien. Ikke desto mindre kommer han ind på en lang række områder, som har antropologers bevågenhed eller ligefrem er centrale for deres fag. I denne artikel vil jeg skildre hovedlinjer i amerikanske antropologers modtagelse af Orientalism i lyset af disse områder, især ideer om viden, magt, kultur og repræsentation.

Den amerikanske litteraturprofessor Timothy Brennan hævder, at Orientalism "is a profoundly American book [that] could not have been written anywhere else" 2 (Brennan 2000:560). Det er ikke helt klart, hvad Brennan mener, men hans påstand bekræftes af, at USA er det land, hvor Orientalism generelt har været genstand for den største opmærksomhed, og også det sted, hvor der er foregået den mest omfattende antropologiske debat om Orientalism og Said (Varisco 2004:94, n. 3). Det hører også med til historien, at USA er en antropologisk stormagt - landet har langt det største antal antropologer i verden. Det er på den baggrund, at jeg fokuserer på Orientalism og amerikansk antropologi.

\section{Antropologi: Barn af imperialismen}

Siden midten af forrige århundrede har antropologer diskuteret emner, som er beslægtede med dem, som Said behandler i Orientalism. Allerede i 1950 tog den franske antropolog Michel Leiris emnet op i "L'ethnographe devant le colonialism" ("The Ethnographer Faced with Colonialism" (Leiris 1989 [1950])). Her pegede han på, at antropologer, som studerede koloniale befolkninger, 
var en del af kolonialismen, uanset om de ville det eller ej. Antropologerne havde derfor et ansvar over for de folk, han eller hun studerede - et ansvar, som bød dem at medvirke til deres frigørelse. I 1950'erne kom de hel- og halvkoloniale krige i Afrika og Asien, og de medførte blandt antropologer en intens selvransagelse og fagkritik, som markant løftede antropologiens faglige og politiske bevidsthedsniveau. Det var især Vietnamkrigen, som skabte en bred mobilisering af antropologer i den vestlige verden, hvor ikke mindst amerikansk antropologi tidligt spillede en væsentlig rolle (Patterson 2001). I et nyligt interview fortæller Marshall Sahlins (2008:220), hvordan han i marts 1965 på University of Michigan fik ideen til den første "teach-in" om Vietnamkrigen. En central person i disse år var Kathleen Gough, som i en artikel, "Anthropology and Imperialism", i Monthly Review, det førende marxistiske tidsskrift i USA, gjorde gældende, at mange nationale befrielsesbevægelser i Den Tredje Verden opfattede antropologernes virksomhed som en integreret del af den amerikanske indblandingspolitik i Den Tredje Verden. Gough nægtede, at antropologien var objektiv og neutral og gjorde gældende, at dens opgave på universiteterne bl.a. var at tjene og legitimere imperialistisk dominanspolitik (Gough 1968a; se også Maquet 1964). Samme år (1968) publicerede hun i Current Anthropology artiklen "New Proposals for Anthropologists" (1968b). I dette bidrag til en kritisk, antropologisk fagetik opfordrede hun til en kollektiv antropologisk besindelse på disciplinens grundlag og tilskyndede til en granskning af, hvilke sociale og politiske interesser, som antropologerne tjente i deres virke.

Kathleen Gough udtrykte, hvad flere antropologer tænkte i 1960'erne og 70'erne, som det fremgår af bl.a. tre antologier publiceret mellem 1969 og 1973: Reinventing Anthropology (Hymes 1969), Ideology in Social Science: Readings in Critical Social Theory (Blackburn 1972) $)^{4}$ og Anthropology and the Colonial Encounter (Asad 1973; se også Leclerc 1972). Bidragyderne til disse bøger stillede spørgsmålstegn ved antropologien og dens teorier og anbefalede at udvikle en refleksiv, kritisk antropologi:

[T]hey pointed to the relationship between anthropology and racism, on the one hand, and the politics of African-American culture, on the other. They deployed concepts - imperialism, exploitation, resistance, neo-colonialism, economic dependency, and hegemony among others - that were more at home in Marxist traditions of social thought than they were in the various strands of social theory taught in American universities at the time (Patterson 2001:127f.).

Jeg har nævnt Kathleen Gough som en central person i den amerikanske kritik af antropologien. Det er dog vigtigt at understrege, at den ikke var en eller få personers værk. Der var tale om en bevægelse med rødder i borgerrettighedsbevægelsen, med et stort engagement i modstanden mod Vietnamkrigen 
og med en stærk repræsentation i studenterbevægelsen. I modsætning hertil var Orientalism et énmandsværk, og forfatteren var outsider i forhold til bogens fagområde (omend insider på det politiske område), hvilket ikke, som bekendt, hindrede, at den fik en betydelig udbredelse og indflydelse. Said publicerede Orientalism en halv snes år efter, at antropologien havde formuleret en dybtgående kritik af sin egen teori og praksis. Hvordan tog antropologerne imod den?

\section{Antropologerne og Orientalism: Modtagelsen}

Orientalism vakte kun ringe opmærksomhed i antropologiske kredse, da den udkom. En søgning i 40 antropologiske, engelsksprogede, internationale tidsskrifter finder kun én anmeldelse i perioden 1978-1983. Det var i American Anthropologist, hvor Roger Joseph skrev en kort anmeldelse (Joseph 1980:948). De fleste anmeldelser skrevet af antropologer blev publiceret i toneangivende tværfaglige eller ikke-antropologiske tidsskrifter som History and Theory (James Clifford) og Comparative Studies in Society and History (Amal Rassam) og The English Historical Review (Talal Asad). Sidstnævnte eksempel er særlig interessant, når det ses i sammenhæng med, at Orientalism ikke er blevet anmeldt i det hæderkronede britiske, antropologiske tidsskrift Man. ${ }^{5}$ Der kan være forskellige forklaringer på denne tilsyneladende beskedne antropologiske interesse for bogen - eller for Said for den sags skyld. Det kunne skyldes, at antropologiske tidsskrifter (bortset fra American Anthropologist) kun anmeldte antropologiske bøger. Det kan også skyldes, at bogen ikke skønnedes at have den fornødne relevans eller aktualitet, fordi - som Charles Lindholm foreslår - antropologerne allerede havde rejst de kritiske spørgsmål og dermed skabt en rammeforståelse af disciplinens teori og praksis (Lindholm 1995). Dette svarer til min egen fornemmelse, da jeg læste bogen i 1978. Ikke at jeg syntes, at bogen var overflødig, men snarere at det var rart at se at litteraterne var vågnet op. Det var også mit indtryk, at interessen for bogen var større i andre humanistiske discipliner. Jeg husker, at jeg læste et review-symposium om Orientalism i Journal of Asian Studies i 1980 (vol. 80, nr. 3). Det fik mig til at tro, at interessen for bogen var større i historikerkredse end blandt antropologer.

\section{0}

Ovenfor nævnede jeg Roger Josephs anmeldelse fra 1980, som er den tidligste og eneste i min søgning, som er publiceret i et antropologisk tidsskrift. Den slutter således:

Said has presented a thesis that on a number of counts is quite compelling. He seems to me, however, to have begged one major question. If discourse, by its very metanature, is destined to misrepresent and to be mediated by all sorts of private agendas, how can we represent cultural systems in ways that will allow us to escape the very dock in which 
Said has placed the Orientalists? The aim of the book was not to answer that question, but surely the book itself compels us to ask the question of its author (Joseph 1980:948, kursiv tilføjet).

Tilsyneladende en positiv bedømmelse: "Ganske overbevisende argument." Denne ros skal dog holdes op mod resten af anmeldelsen: Hvis diskursen, man er underlagt, skaber misrepræsentation, hvordan kan man da undgå at misrepræsentere? Det spørgsmål burde Said have besvaret, slutter Joseph. Det er en kritik, som mødte Said igen og igen, fordi han ikke gav nogen forslag til, hvordan man kunne foretage ikke-orientaliserende repræsentationer. Saids egen metode gav kun få anvisninger, siger Daniel Martin Varisco, den er en:

cut-and-paste variety - a dash of Foucauldian discourse here and a dram of Gramscian hegemony there - rather than a how-to model (Varisco 2007:291).

Samme år, som Josephs korte anmeldelse udkom, publicerede James Clifford en meget lang (20 sider) anmeldelse af Orientalism i tidsskriftet History and Theory (Clifford 1988b). Hvor Joseph nøjedes med at konstatere, at Said ignorerede problemer, som hans brug af diskursbegrebet skabte, tog Clifford sig tid til at udfolde, hvori problemerne bestod. I introduktionen til Orientalism fremlagde Edward Said sine teoretiske præmisser og anfører bl.a.:

I have found it useful here to employ Michel Foucault's notion of discourse, as described by him in The Archaeology of Knowledge and in Discipline and Punish, to identify Orientalism (Said 1978:3).

Tyve sider længere fremme i introduktionen modificerede han sit standpunkt:

Yet, unlike Michel Foucault, to whose work I am greatly indebted, I do believe in the determining imprint of individual writers upon the otherwise anonymous collectice body of texts constituting a discoursive formation like Orientalism (Said 1978:23),

og føjede derefter til:

Foucault believes that in general the individual text or author counts for very little; empirically, in the case of Orientalism (and perhaps nowhere else) I find this not to be so (Said 1978:23).

James Cliffords kritik satte ind i forhold til Saids inkonsistente brug af Foucaults diskursbegreb: 
The problem with the book, at least from a theoretical standpoint, is its title. In attempting to derive a "discourse" directly from "tradition," Said abandons the level of cultural criticism proposed by Foucault and relapses into traditional intellectual history. Moreover, in portraying the discourse as based on essentially nineteenth-century modes of thought, Said gives himself too easy a target. He does not question anthropological orthodoxies based on a mythology on fieldwork encounter and a hermeneutically minded cultural theory - orthodoxies he often appears to share (Clifford 1988b:268).

For Foucault var traditioner effekter af diskurser. For Said var det - somme tider - omvendt. Det var ikke Saids hensigt at lave helt om på Foucaults ideer, snarere udvide dem, så diskurser kunne siges at eksistere side om side med autonome individer. Det var derfor han i sin diskussion af tradition og diskurs valgte at operere med, hvad han kaldte "a hybrid perspective", et "blandingssyn", hvormed han kunne undersøge både det diskursive og aktørcentrerede felt. Som nævnt ovenfor hævdede Said:

Foucault believes that in general the individual text or author counts for very little; empirically, in the case of Orientalism (and perhaps nowhere else) I find this not to be so (Said 1978:23).

Hertil siger Clifford:

This doggedly empirical and curiously qualified assertion separates Said sharply from Foucault. What is important theoretically is not what Foucault's author counts for very little but rather that a "discursive formation" - as opposed to ideas, citations, influences, references, conventions, and the like - is not produced by authorial subjects or even by a group of authors arranged as a "tradition". This methodological (not empirical) point is important for anyone involved in the kind of task Said is attempting. One cannot combine within the same analytic totality both personal statements and discursive statements, even though they may be lexically identical. Said's experiment seems to show that when the analysis of authors and traditions is intermixed with the analysis of discursive formations, the effect is a mutual weakening (Clifford 1988b:269).

Man kan, med andre ord, ikke påkalde sig en diskursiv determinisme i samme analytiske åndedrag, som man forfægter en metodologisk individualisme. De to tilgange udelukker hinanden.

I slutningen af Orientalism skrev Said, at hans hensigt med bogen var at beskrive orientalismen, ikke at fremlægge et alternativ til den. Han tilføjede 
dog et par bemærkninger, som antyder, hvor problemerne lå:

How does one represent other cultures? Is the notion of a distinct culture (or race, or religion, or civilization) a useful one? (Said 1978:325, kursiv tilføjet)

og lidt længere fremme tilføjer han:

that the notion that there are geographical spaces with indigenous, radically "different" inhabitants, who can be defined on the basis on some religion, culture, or racial essence proper to that geographical space is a highly debatable idea (Said 1978:332).

Clifford tog i sin anmeldelse spørgsmålet op til overvejelse og skrev:

It is high time that cultural and social totalities are subjected to radical questioning [...] Saids attack on essences and oppositional distinctions is here very much to the point;

og han fortsatte:

but collectively constituted difference is not necessarily static or positionally dichotomous in the manner of Orientalism as Said describes it. There is no need to discard theoretically all conceptions of "cultural" difference, especially once this is seen as not simply received from tradition, language or environment but also made in new political-cultural conditions of global relationality [...] But however the culture concept is finally transcended, it should, I think, be replaced by some set of relations that preserves the concept's differential and relativist functions (Clifford 1988b:274).

Diskussionen af diskurs- og kulturbegrebet fyldte meget i Cliffords anmeldelse. Clifford gik stærkt i rette med Saids metodologi, som han kaldte "ambivalent" (Clifford 1988b:275; Boon 1982) ${ }^{6}$. Clifford syntes dog at have større forståelse for Said, når det kom til kulturbegrebet. Det er imidlertid en diskussion, som først blusser op omkring 1990, hvorfor jeg vender tilbage til den nedenfor.

\section{6}

Midt i 1980'erne udkom to vigtige antropologiske værker, som samlede erfaringerne med at forny den antropologiske kritik, som udvikledes i 1960'erne og 70'erne. Det drejer sig om Writing Culture: The Poetics and Politics of Ethnography (Clifford og Marcus, ed., 1986) og Anthropology as Cultural Critique: An 
Experimental Moment in the Human Sciences (Marcus og Fischer 1986). Under indflydelse af "den sproglige vending" og den ledsagende repræsentationsskepsis fokuserede de på antropologiens konventionelle repræsentationsformer og stillede spørgsmålstegn ved disses evne til at afbilde virkeligheden, ligesom de søgte at udvikle nye og mere gyldige måder at beskrive virkeligheden på.

Orientalism blev kun nævnt ganske kort et par gange i Writing Culture, dog ofredes der en enkelt gang 14 linjer på den, hvor den omtaltes under genrebetegnelsen "polemik" (Clifford og Marcus 1986:12). I Anthropology as Cultural Critique var Said helt anderledes til stede. Allerede på bogens tre første sider blev Orientalism præsenteret. Bl.a. konstaterede Marcus og Fischer, at antropologien også var under anklage i Saids projekt:

Edward Said's Orientalism is an attack on the genres of writing developed in the West to represent non-Western societies. His brush is broad and indiscriminate. At one point, he seems to exempt contemporary cultural anthropology by brief favourable mention of one of its masters, Clifford Geertz, but this is ambiguous, and [...] and it is clear that he intends his condemnations to apply to all Westerners writing about others, including anthropologists (Marcus og Fischer 1986:1).

Præsentationen fortsatte med et kort rids af Orientalism's argument, som efterfulgtes af et længere afsnit, hvor forfatterne gav deres mening til kende om bogen. Jeg citerer denne del i sin helhed for at give et indtryk af den polemik, som var i gang:

Yet, Said poses in his book no alternative form for the adequate representation of other voices or points of view across cultural boundaries, nor does he install any hope that this might be possible. He in fact practices the same sort of rhetorical totalitarianism against his chosen enemies as he condemns. He acknowledges no motives of the West other than domination, no internal debates among westerners about alternative modes of representation, no historical change from the days of open imperialism (from where he exclusively draws his close analyses of rhetoric) to the present. Most tellingly he acknowledges no political or cultural divisions among the subject peoples he is allegedly defending. These last have no more independent voice in his text than in that of any other Western writer. However, the very duality in Said's own personal position serves to express eloquently the political context in which writing and scholarship on other cultures occur. As a Palestinian and as a prominent literary scholar in an American University, he is both a member of an uprooted dominated culture and a privileged intellectual of the dominating one. 
Said, finally has chosen to fight with fire, and his work is effective only as polemic. Without sufficient demonstration, he suggests that the world written about is often quite different from that imagined in the writings of disciplines like anthropology, which take it upon themselves to represent authoritatively alternative social and cultural forms of life contrasting with those of the West. For those in such disciplines, the urgent task remains to rethink and experiment with their conventional forms of writing in response to what is, after all, a trenchant critique in Said's polemic. [...] In their predominant concern with the description and analysis of non-Western cultures, anthropologists have been developing their own Saidian self-critiques, most strongly since the 1960s. The results are now beginning to be incorporated effectively into the research process and especially into the ways other cultures are being written about. Experimental strategies to alter the standard forms of anthropological accounts are expressing, on the one hand, a new sensitivity to the difficulty of representing cultural differences, given current, almost overriding, perceptions of the global homogenization of cultures, and on the other, a sophisticated recognition of the historical and political-economic realities which, while not denied, have been elided or finessed in much past writing (Marcus og Fischer 1986:2-3).

Der er tydeligvis megen polemik og retorik i denne antropologiske selvfremstilling. Det er ikke en frugtbar dialog, der her foregik, men en symbolsk kamp mellem konkurrerende parter i et akademisk-politisk felt. Kampen fandt dog sted i separate fora. Året efter, i 1987, blev Said og antropologerne konfronteret med hinanden.

\section{7}

Edward Said blev inviteret til at holde en forelæsning ved "86th Annual Meeting of American Anthropological Association" i Chicago den 21. november 1987. Det skete ved en session, som kaldtes "Anthropology's Interlocutors: Edward Said and Representations of the Colonized". En redigeret udgave af forelæsningen udkom med titlen "Representing the Colonized: Anthropology's Interlocutors" i Critical Inquiry i 1989 (Said 1989). Said lagde i sin forelæsning ikke skjul på, at han mente, at Orientalism var blevet fjendtligt modtaget af antropologerne:

It has appeared to me particularly significant that anthropologists, and not historians for instance, have been among the most unwilling to accept the rigors of [my approach] (Said 1989:211).

Dette spillede formentlig en rolle for forelæsningens meget skarpe tone. Her følger er par uddrag. Saids budskab var, at "antropologien" direkte eller in- 
direkte arbejdede på den imperialistiske ideologis præmisser, fordi den ikke havde brudt forbindelsen til det amerikanske empirium ("empire") og enten ikke havde forstået det eller ikke ville være ved det:

I am impressed that in so many of the various writings on anthropology, epistemology, textualization, and otherness that I have read [...] there is an almost total absence of any reference to American imperial intervention as a factor affecting the theoretical discussion (Said 1989:214).

Antropologien var medskyldig i imperialismens undertrykkelse, og i den situation var det:

irresistible to argue that the vogue for thick descriptions and blurred genres acts to shut and block out the clamor of voices on the outside asking for their claims about empire and domination to be considered. The native point of view, despite the way it has often been portrayed, is not an ethnographic fact only, is not a hermeneutical construct primarily or even principally; it is in large measure a continuing, protracted, and sustained adversarial resistance to the discipline and the praxis of anthropology (as representative of "outside" power) itself, anthropology not as textuality but as an often direct agent of political dominance (Said 1989:219-20).

Denne udtalelse har en undertekst: "Thick description", "blurred genres" og "the native point of view" er alle taget fra artikler, som er skrevet af Clifford Geertz, én af tidens mest respekterede og indflydelsesrige antropologer. En halv snes år før havde Said i Orientalism omtalt Geertz' arbejde som "excellent" og rost hans interersse for islam for at være:

discrete and concrete enough to be animated by the specific societies and problems he studies and not by the rituals, preconceptions, and doctrines of Orientalism (Said 1978:326).

Denne undertekst er det tætteste, man kan komme på at erklære krig uden at sige det.

I sine slutbemækninger funderede Said over, om antropologien var tvunget til at være på den forkerte side af det imperiale skel og endte med - måske - at se en fremtid for disciplinen:

I cannot say whether it is now possible for anthropology as anthropology to be different, that is, to forget itself and to become something else as a way of responding to the gauntlet thrown down by imperialism 
and its antagonists. Perhaps anthropology as we have known it can only continue on one side of the imperial divide, there to remain as a partner in domination and hegemony.

On the other hand, some of the recent anthropological efforts critically to re-examine the notion of culture top to bottom may be starting to tell a different story. If we no longer think of the relationship between cultures and their adherents as perfectly contiguous, totally synchronous, wholly correspondent, and if we think of cultures as permeable and, on the whole, defensive boundaries between polities, a more promising situation appears (Said 1989:225). ${ }^{7}$

\section{Kulturbegrebet: En afslutning}

Efter Saids forelæsning i Chicago 1987 og publiceringen af "Representing the Colonized: Anthropology's Interlocutors" i 1989 blev der ikke arrangeret flere møder eller på anden måde søgt at gøre livet til et valg mellem Saids lære og antropologi. Said havde både tilhængere og modstandere blandt antropologerne, og sådan var det formodentlig i alle humanistiske og samfundsvidenskabelige universitetsdiscipliner. Det var altså et meget broget billede, der tegnede sig.

I 1980 havde James Clifford vist forståelse for Saids kritik af kulturbegrebet, og i 1987 udtrykte Said imødekommenhed over for de antropologiske kulturbegrebslige genovervejelser. Måske var dette et emne, som de stridende parter kunne tale om. I antropologien var det sådan, at tilhængere af det "klassiske" kulturbegreb var modstandere af Said, og at kritikere af det var tilhængere af Said, og mon ikke mønstret var sådan andre steder? Det får være, som det vil. Den følgende omtale af diskussionen om kulturbegrebet er kortfattet og sigter først og fremmest på at eksemplificere, at 1980'ernes ophedede og personfikserede diskussion om Orientalism kunne fortsætte under mere afpersonaliserede former, samtidig med at de rettede sig mod analytiske emner og ikke mod ikoner som Said og Orientalism.

I 1991 publicerede antropologen Lila Abu-Lughod "Writing Against Culture", en artikel som blev overordentlig indflydelsesrig. Lila Abu-Lughod er amerikansk-palæstinensisk antropolog og professor i antropologi på Columbia University, Said's universitet. I 1986 publicerede hun Veiled Sentiments: Honor and Poetry in a Bedouin Society, en meget rost monografi baseret på feltarbejde hos Awlad 'Ali, et beduinsamfund i det vestlige Ægypten. Lila AbuLughods far var Ibrahim Abu-Lughod, amerikansk-palæstinensisk professor i statskundskab Northwestern University og rektor på Birzeit University på Vestbredden. Han var en meget nær ven af Said, som tilegnede Orientalism til ham. Ibrahim Abu-Lughod var ligesom Said medlem af Det Palæstinensiske Nationalråd. Abu-Lughod's artikel indgik i Richard G. Fox's antologi Recapturing Anthropology: Working in the Present (1991), som sammen med tidligere omtalte Marcus og Fishers Anthropology as Cultural Critique (1986) og Clifford 
og Marcus's Writing Culture (1986), præsenterede tidens avantgardeantropologi. "Writing Against Culture" fulgte op på Saids ideer om kulturbegrebets essentialiserende og reificerende betydning for repræsentationen af befolkningsgrupper. Abu-Lughod argumenterede for, at:

"culture" operates in anthropological discourse to enforce separations that invariably carry a sense of hierarchy. Therefore, anthropologists should now pursue [...] a variety of strategies for writing against culture (Abu-Lughod 1991:138).

Hun konkretiserede Saids kritik af kulturbegrebet, og gjorde gældende, at:

[d] espite its anti-essentialist intent, [...] the culture concept retains some of the tendencies to freeze difference possessed by concepts like race (Abu-Lughod 1991:144).

Kultur, hævdede hun:

is the essential tool for making other. As a professional discourse that elaborates on the meaning of culture in order to account for, explain, and understand cultural difference, anthropology also helps construct, produce, and maintain it. Anthropological discourse gives difference (and the separation between groups of people it implies) the air of the self-evident (Lughod 1991:143).

Hun understregede, at:

[i]t would be worth thinking about the implications of the high stakes anthropology has in sustaining and perpetuing a belief in the existence of cultures that are identifiable as discrete, different, and separable from our own (Abu-Lughod 1991:146, se også Abu-Lughod 1993).

I 1999 publicerede antropologen Christoph Brumann artiklen "Writing for Culture: Why a Successful Concept Should Not be Discarded" (Brumann 1999) i Current Anthropology. Artiklen blev kommenteret af seks antropologer, blandt hvilke var Abu-Lughod. I artiklen gjorde Brumann gældende, at de antropologer, der som Abu-Lughod (1991) skrev mod kultur, refererede til "certain uses of the culture concept rather than the concept itself" (Brumann 1999:S1). Brumann udledte heraf, at der ikke var noget i selve begrebet, som gjorde det skadeligt, og at opmærksomheden måtte rettes mod brugen for at mindske skadelig brug. I denne forbindelse er det især interessant, hvad AbuLughod siger til Brumanns synspunkt. Hun sammenfatter det således: 
I give greater weight to the social and political life of the concept as it has developed historically. I thus question its continuing usefulness. It is, perhaps as Brumann suggests, a case of the cup half-full or halfempty (Abu-Lughod 1999: S15).

Jeg hæfter mig ved den afvæbnende åbenhed i den sidste sætning, altså ved at Abu-Lughod kan acceptere, at problemet er perspektivafhængigt. Sådan kunne uenigheder om kulturbegrebets grundlæggende beskaffenhed sjældent håndteres i 1980'erne, da det nemt ville blive trukket ind i en stillingtagen for eller imod Said og Orientalism. Jeg synes, dette er et fremskridt.

\section{Poul Pedersen}

E-mail: poul.pedersen@hum.au.dk

\section{Noter}

1. Malcolm Kerr var professor på University of California, Los Angeles. I 1982 blev han president for American University of Beirut. To år senere blev han myrdet uden for sit kontor af to terrorister fra Islamic Jihad (van de Ven 2008).

2. Brennan mener også - til stor overraskelse for mange - at Orientalism var en kritik af postkolonialismen og ikke dens grundlag, som det almindeligvis antages.

3. Goughs artikel gives ofte fejlagtigt titlen "Anthropology: Child of Imperialism". Det skyldes, at den på forsiden af det nummer af Monthly Review, hvori den blev publiceret, præsenteres med denne titel. I indholdsfortegnelsen og inden i tidsskriftet optræder den under titlen "Anthropology and Imperialism."

4. Robin Blackburn er ikke antropolog, men historiker og sociolog. Bogen indeholder adskillige antropologiske bidrag.

5. Man, som udgives af The Royal Anthropological Institute i London, skiftede i 1995 navn til Journal of The Royal Anthropological Institute.

6. Tak Til Jonathan Schwartz for henvisningen til Boon.

7. Antropologen Michaela Di Leopardi deltog i mødet med Said og giver en interessant øjenvidneskildring (Di Leonardo 1998:46-51, 379-380).

\section{Litteratur}

Abu-Lughod, Lila 1991: “Writing Against Culture”, i Fox, Richard G. (ed.) 1991: Recapturing Anthropology: Working in the Present. Santa Fee: School of American Research Press, 138-62.

Abu-Lughod, Lila 1993: Writing Women's World: Bedouin Stories. Berkeley: University of California Press.

Abu-Lughod, Lila 1999: "Comment". Current Anthropology, 40, Supplement: Special Issue: Culture: A Second Chance?, S13-S15.

Asad, Talal, ed. 1973: Anthropology and the Colonial Encounter. London: Ithaca Press.

Blackburn, Robin 1972: Ideology in Social Science: Readings in Critical Social Theory. New York: Pantheon Books.

Boon, James A. 1982: Other Tribes, Other Scribes: Symbolic Anthropology in the Comparative Study of Cultures, Histories, Religions, and Texts. Cambridge: Cambridge University Press. 
Brennan, Timothy 2000: "The Illusion of a Future: "Orientalism" as Traveling Theory", Critical Inquiry 26, 558-583.

Brumann, Christoph 1999: "Writing for Culture: Why a Successful Concept Should Not be Discarded," Current Anthropology, 40, Supplement: Special Issue: Culture: A Second Chance?, S1-S27.

Clifford, James 1988a: The Predicament of Culture: Twentieth-Century Ethnography, Literature, and Art. Cambridge, Mass: Harvard University Press.

Clifford, James 1988b: “On Orientalism." I: The Predicament of Culture: Twentieth-Century Ethnography, Literature, and Art. Cambridge, Mass: Harvard University Press, 255276 (Først publiceret som “Edward Said, Orientalism", History and Theory, 19 (1980): 204-223).

Clifford, James og George E. Marcus (ed.) 1986: Writing Culture: The Poetics and Politics of Ethnography. Berkeley: University of California Press.

Di Leonardo, Michaela 1998: Exotics at Home: Anthropologies, Others, American Modernity. Chicago: University of Chicago Press.

Eriksen, Thomas Hylland 2003: "Edward Said - en intellektuel kosmopolit", Dagbladet Information, 2. oktober 2003, side 10, http://www.information.dk/86218 (27. oktober 2008).

Fox, Richard G. (ed.) 1991: Recapturing Anthropology: Working in the Present. Santa Fee: School of American Research Press.

Gough, Kathleen 1968: "Anthropology and Imperialism", Monthly Review, 19 (11), $12-$ 27.

Hymes, Dell (ed.) 1969: Reinventing Anthropology. New York: Random House.

Joseph, Roger 1980: "Review of Orientalism by Edward Said". American Anthropologist, 82,948 .

Kerr, Malcolm 1982: "Edward Said, Orientalism", International Journal of Middle Eastern Studies, 12, 544-547.

Leclerc, Gérard 1972: Anthropologie et colonialisme. Paris: Fayard.

Leiris, Michel 1989: “The Ethnographer Faced with Colonialism”, i Brisées: Broken Branches. San Francisco: North Point Press, pp. 112-131 (først trykt som "L'ethnographe devant le colonialism" i Les Temps moderns (Paris), 6, nr. 3, 1950).

Lindholm, Charles 1995: "The New Middle Eastern Ethnography". Journal og the Royal Anthropological Institute, 1, 805-20.

Marcus, George E. og Michael J. Fisher (eds.) 1986: Anthropology as Cultural Critique: An Experimental Moment in the Human Sciences. Chicago: The University of Chicago Press.

Maquet, Jacques 1964: "Objectivity in Anthropology". Current Anthropology 5:47-55.

Patterson, Thomas C. 2001: A Social History of Anthropology in the United States. Oxford: Berg.

Pedersen, Poul 1998: "After "Orientalism": Prisoners of Shangri-La and Kierkegaard Made in Japan". Folk: Journal of the Danish Ethnographic Society, 40, 171-192.

Sahlins, Marshall 2008: “Interview with Marshall Sahlins". Anthropological Theory 8, 3, 319-328.

Said, Edward 1978: Orientalism. London: Routledge \& Kegan Paul.

Said, Edward 1989: “Representing the Colonized: Anthropology's Interlocutors”. Critical Inquiry, 15, 205-225. 
van de Ven, Susan Kerr 2008: One Family's Response to Terrorism: A Daughters Memoir. New York: Syracuse University Press.

Varisco, Daniel Martin 2004: "Reading Against Culture in Edward Said's Culture and Imperialism". Culture, Theory \& Critique, 45(2), 93-112.

Varisco, Daniel Martin 2007: Reading Orientalism: Said and Unsaid. Seattle: University of Washington. 